\title{
Resistance of mice to genital infection with Neisseria gonorrhoeae
}

\author{
A.P. JOHNSON*, M. TUFFREY and D. TAYLOR-ROBINSON
}

Division of Sexually Transmitted Diseases, M.R.C. Clinical Research Centre, Watford Road, Harrow, Middlesex HA1 3UJ

Summary. Five strains of mice (C3H, CBA, BALB/c, TO and ICR) were inoculated intra-vaginally with Neisseria gonorrhoeae in an attempt to produce an animal model of gonorrhoea. Of a total of 68 mice inoculated, only three $\left(4 \cdot 4^{\%} \%\right)$ were culturepositive after 3 days. Histological examination of both the genital mucosa of inoculated animals, and the mucosa of genital tract organ cultures inoculated in vitro failed to show any evidence of gonococcal adherence or colonisation. Mice of these strains, therefore, appear resistant to gonococcal infection of the genital tract.

\section{Introduction}

One of the major difficulties confronting investigators studying the pathogenesis of gonococcal infections is the lack of a convenient animal model. Although gonococcal urethritis has been produced experimentally in chimpanzees (Chandler and Kraus, 1976), attempts to infect the genital tract of other animal species including baboons ( $\mathrm{Di}$ Giacomo et al., 1977), pig-tailed macaques (Gale et al., 1977), rhesus monkeys, squirrel monkeys, owl monkeys, capuchin monkeys (Chandler and Kraus, 1976), marmosets (Johnson, Hetherington and Taylor-Robinson, unpublished observations), rabbits (Taylor-Robinson et al., 1974) and guinea-pigs (Tebbutt et al., 1977) have been unsuccessful. In addition, inoculation of gonococci into either the respiratory tract (Johnson et al., 1977b) or mammary gland (Taylor-Robinson et al., 1975) of mice, failed to produce infection. In contrast to these findings, however, Kita et al. (1981) reported successful experimental gonococcal infection of the genital tract of mice of the ddY strain. In this study we report the results of our attempts to produce experimental gonococcal infection in the genital tract of five strains of mice that are, in contrast to the ddY strain, readily available for study in the United Kingdom.

Received 13 Dec. 1988; accepted 13 Feb. 1989.

*Present address : Antibiotic Reference Laboratory, Division of Hospital Infection, Central Public Health Laboratory, Colindale, London NW9 5HT.

\section{Materials and methods}

\section{Bacteria}

Neisseria gonorrhoeae strains 818 and 831 were isolated from patients with gonorrhoea attending the Praed Street Clinic, Paddington, London. Strain 73747 was isolated from a baby's eye at Northwick Park Hospital, Harrow, and strain $203 \mathrm{H}$ was provided by Professor Z. A. McGee, Centre for Diagnostic Microbiology and Immunology, University of Utah. Organisms were grown on GC Agar Base (Difco) supplemented with IsoVitalex (BBL) $2 \%$ (hereafter referred to as GC+ ISO) in an atmosphere of $\mathrm{CO}_{2} 5 \%$ in air at $37^{\circ} \mathrm{C}$. Only cultures which produced predominantly type I colonies (Kellogg et al., 1963) were used.

\section{Mice}

Young adult female mice weighing about $20 \mathrm{~g}$ were used. Mice of the $\mathrm{C} 3 \mathrm{H}, \mathrm{CBA}$, TO and BALB/c strains were bred at the Clinical Research Centre, and mice of the inbred ICR strain were obtained from the Animal Unit, University of Dundee.

\section{Inoculation procedure}

Bacteria were cultured for $18 \mathrm{~h}$ as described above and the resulting growth was scraped from the agar surface with a loop and suspended in $3 \mathrm{ml}$ of Eagle's Minimal Essential Medium (MEM) maintained at $\mathrm{pH} 7.2$ with 0.05 м HEPES buffer. Clumps of bacteria were broken up with a needle and syringe. A small volume of bacterial suspension $(10-20 \mu \mathrm{l})$ was then inoculated into the vagina of unanaesthetised mice with an Eppendorf pipette. The 
number of viable bacteria in each inoculum was determined by making serial 10 -fold dilutions and plating $0.1 \mathrm{ml}$ on the medium described above, and counting the number of colonies produced after incubation for 18$24 \mathrm{~h}$. In some experiments, vaginal swabs were taken before inoculation, and used to prepare smears which were stained by Gram's method and examined microscopically to determine the stage of the oestrous cycle at the time of inoculation.

In one experiment, mice were pre-treated with progesterone and then inoculated by intra-uterine injection of the utero-tubal junction, as described previously (Tuffrey and Taylor-Robinson, 1981).

\section{Isolation of $N$. gonorrhoeae from the genital tract}

Three to 5 days after inoculation, the lower genital tract of each mouse was sampled by inserting a nasopharyngeal calcium alginate swab (Wilson Diagnostics Inc., IL, USA) into the vagina. Each swab was then inoculated on to GC + ISO medium, and the plates were incubated for at least 2 days at $37^{\circ} \mathrm{C}$ in an atmosphere of $\mathrm{CO}_{2} 5 \%$. In some experiments additional swabs were obtained and plated on GC + ISO medium supplemented with vancomycin $5 \mu \mathrm{g} / \mathrm{ml}$ and colistin $3 \mu \mathrm{g} / \mathrm{ml}$. Possible colonies of $N$. gonorrhoeae were subcultured and characterised by colonial morphology, Gram's stain, oxidase test and sugar fermentation reactions.

In two experiments the mice were killed by intraperitoneal injection of sodium pentabarbitone followed by bleeding from the axillary vessels, and the vaginalcervical region of the genital tract, and the uterine horns, were removed aseptically and homogenised in $1 \mathrm{ml}$ of MEM. Small samples (about $0.1 \mathrm{ml}$ ) were then inoculated on to GC+ISO medium and incubated as described above.

\section{Histopathology}

In two experiments, mice were killed and the genital tract was removed and fixed in formol sublimate. The fixed tissues were then processed by routine histological methods and sections stained with Gram-methyl greenpyronin-light green stain, which was developed specifically for the purpose of detecting bacteria in tissue sections (Sowter and McGee, 1976).

\section{Organ cultures of mouse genital mucosa}

Organ cultures of mouse cervix and vagina, and uterine horn, were prepared and inoculated as described previously for organ cultures of guinea-pig genital tissue (Johnson et al., 1980). Briefly, the genital tract was removed and placed in a petri dish containing MEM supplemented with vancomycin and colistin. The uterine horns were separated with a scalpel from the lower region of the genital tract, transferred to fresh medium and cut open longitudinally to expose the mucosal surface. The vaginal-cervical region of the genital tract was treated similarly. The medium was then removed, and $50 \mu \mathrm{l}$ of a suspension of gonococci were placed directly on to the mucosal surface of each piece of tissue. The inoculated tissues were incubated in a moist environment for $1 \mathrm{~h}$ at $37^{\circ} \mathrm{C}$ after which they were gently rinsed five times with phosphate-buffered saline to remove non-adherent bacteria. The tissue pieces were then fixed and stained as described above, and examined microscopically to detect adherent bacteria.

\section{Results}

\section{Isolation of gonococci}

The results of six experiments in which mice were inoculated with gonococci are summarised in the table. In three experiments (nos. 1, 2 and 6) the stage of the oestrous cycle of each mouse at the time of inoculation was determined. Four of six $\mathrm{C} 3 \mathrm{H}$ mice and nine of $10 \mathrm{CBA}$ mice were at early oestrous. The oestrous cycle of two $\mathrm{C} 3 \mathrm{H}$ mice could not be determined as there were insufficient vaginal cells on the smear, while one CBA mouse was at early metoestrous. Four of seven ICR mice were at oestrous, the other three being at dioestrous. In four experiments involving TO, ICR and BALB/c mice (some of which had been treated with progesterone), gonococci were not recovered from any swabs taken 3 and 5 days after inoculation. They were recovered in small numbers from one of six $\mathrm{C} 3 \mathrm{H}$ mice sampled on days 3 and 4 but not when this mouse was swabbed on day 5 . In another experiment gonococci were isolated from two of $10 \mathrm{CBA}$ mice sampled 3 days after inoculation, but they were not isolated from any of the mice on day 4. Furthermore, although the genital tracts of all the CBA and ICR mice were homogenised after the final swabs had been obtained, organisms were not isolated from the homogenates. Thus, gonococci were isolated from only three of a total of 68 mice $(4 \cdot 4 \%)$.

\section{Histopathology}

In two experiments (nos. 3 and 4), the genital tract was removed for histopathological study. Examination of sections of the cervico-vaginal region and the uterine horns, failed, however, to reveal evidence of gonococcal association with the mucosa in any of the animals.

\section{Organ culture studies}

Organ cultures of cervico-vaginal and uterine mucosa from CBA and BALB/c mice were each 
Table. Isolation of gonococci from mice

\begin{tabular}{|c|c|c|c|c|c|c|c|}
\hline \multirow[b]{2}{*}{$\begin{array}{l}\text { Experiment } \\
\text { no. }\end{array}$} & \multicolumn{2}{|r|}{ Mice } & \multicolumn{2}{|c|}{ Inoculum } & \multicolumn{3}{|c|}{$\begin{array}{l}\text { Number of mice colonised on } \\
\text { indicated day after inoculation }\end{array}$} \\
\hline & Strain & $\begin{array}{c}\text { Number of animals } \\
\text { inoculated }\end{array}$ & $\begin{array}{l}\text { Strain of } \\
\text { N. gonorrhoeae }\end{array}$ & $\begin{array}{l}\text { Number of organ- } \\
\text { isms (cfu) }\end{array}$ & 3 & 4 & 5 \\
\hline 1 & $\mathrm{C} 3 \mathrm{H}$ & 6 & 818 & $1.8 \times 10^{7}$ & 1 & 1 & 0 \\
\hline 2 & CBA & 10 & 818 & $5.0 \times 10^{7}$ & 2 & $0^{*}$ & \\
\hline 3 & TO & 25 & 831 & $5.0 \times 10^{6}$ & 0 & & 0 \\
\hline 4 & $\begin{array}{l}\text { BALB/c } \\
\text { BALB/c } \dagger\end{array}$ & $\begin{array}{l}5 \\
5\end{array}$ & $\begin{array}{l}73747 \\
73747\end{array}$ & $\begin{array}{l}3.2 \times 10^{7} \\
1.6 \times 10^{8}\end{array}$ & $\begin{array}{l}0 \\
0\end{array}$ & & $\begin{array}{l}0 \\
0\end{array}$ \\
\hline \multirow[t]{2}{*}{5} & BALB/c & 5 & $203 \mathrm{H}$ & $2.0 \times 10^{7}$ & 0 & & 0 \\
\hline & $\mathrm{BALB} / \mathrm{c} \dagger$ & 5 & $203 \mathrm{H}$ & $1.0 \times 10^{8}$ & 0 & & 0 \\
\hline 6 & ICR & 7 & 831 & $6.0 \times 10^{7}$ & 0 & & $0^{*}$ \\
\hline
\end{tabular}

*In addition to taking swabs, attempts were made to isolate gonococci from genital tissue homogenates.

†Pre-treated with progesterone and inoculated by intra-uterine injection.

inoculated with type 1 gonococci of strains $192 \mathrm{~A}$ and 2682. In none of these experiments was there any histological evidence of gonococcal association with mucosal tissue.

\section{Discussion}

Kita et al. (1981) have reported successful gonococcal infection of the genital tract of female mice of the ddY strain. As this strain is not, however, readily available to workers in the UK, we investigated the susceptibility to gonococcal infection of other strains of mice. The results presented here indicate that five commonly available strains of mice are resistant to gonococcal infection of the genital tract. While these findings are at variance with those of Kita et al. (1981), they are consistent with the previously reported resistance of mice to gonococcal infection of the respiratory tract and mammary gland (Johnson et al., 1977b; Taylor-Robinson et al., 1975).

The failure to infect mice in the present study is unlikely to be a reflection of the strains of $N$. gonorrhoeae used to inoculate the animals. Four strains were used, each of which had been subcultured only 2-7 times following isolation. Furthermore, all the inocula consisted predominantly $(>95 \%$ ) of colonies of morphology type 1 , a phenotype strongly associated with virulence (Kel$\log$ et al., 1963). The failure to infect mice is also unlikely to be due to inoculation of animals at an inappropriate stage of the oestrous cycle. Braude $e t$ al. (1978) and Kita et al. (1981) reported that mice were most susceptible to infection at proestrous and oestrous, and less susceptible at metoestrous and dioestrous. In three experiments in which the stage of the oestrous cycle at the time of inoculation was determined, the majority of the mice were at oestrous. In addition, groups of $B A L B / c$ mice were pre-treated with the hormone progesterone. Although such treatment has been shown to enhance the susceptibility of mice to genital infection with a number of pathogens including Chlamydia trachomatis (Tuffrey and Taylor-Robinson, 1981), herpes simplex virus (Baker and Plotkin, 1978) and Mycoplasma pulmonis (Furr and Taylor-Robinson, 1984), it did not increase the susceptibility of mice to gonococcal infection.

A correlation between susceptibility of a host to genital infection with $N$. gonorrhoeae and the susceptibility of that host's genital mucosa to gonococcal adherence has been demonstrated in organ cultures of genital tissue. Genital mucosa from two susceptible species, namely man and chimpanzee, has been shown to be susceptible to gonococcal adherence in vitro (Johnson et al., 1977a; Gregg, McGee, Johnson, Kalter and Taylor-Robinson, unpublished observation), whereas gonococci fail to adhere to oviduct mucosa of resistant species, including rabbits, guinea-pigs and baboons (Johnson et al., 1977a, 1980; Gregg et al., unpublished observation). Thus, a possible explanation for the general lack of susceptibility of mice (other than those of the ddY strain) to infection with $N$. gonorrhoeae is that gonococci are unable to adhere to the genital tract mucosa and thus colonise and infect tissue. This. concept is supported by the histopathological observations on murine genital 
mucosa inoculated both in vivo and in vitro which failed to provide evidence of gonococcal adherence to epithelial cells. In the absence of such adherence, the organisms may not be able to resist the flushing action of uro-genital secretions and thus fail to colonise and infect the genital mucosa.

\section{REFERENCES}

Baker D A, Plotkin S A 1978 Enhancement of vaginal infection in mice by herpes simplex virus type II with progesterone. Proceedings of the Society for Experimental Biology and Medicine 158: 131-134.

Braude A L, Corbeil L B, Levine S, Ito J, McCutchan J A 1978 Possible influences of cyclic menstrual changes on resistance to the gonococcus. In: Brooks G F et al. (eds) Immunobiology of Neisseria gonorrhoeae. American Society for Microbiology, Washington DC, pp 307-313.

Chandler F W, Kraus S J 1976 Animal model of human disease: Experimental gonorrhea in the chimpanzee. American Journal of Pathology 82: 437-440.

DiGiacomo R F, Gale J L, Holmes K K, Buchanan T M 1977 Genital inoculation of male baboons with Neisseria gonorrhoeae. Infection and Immunity 15: 670-671.

Furr P M, Taylor-Robinson D 1984 Enhancement of experimental Mycoplasma pulmonis infection of the mouse genital tract by progesterone treatment. Journal of Hygiene 92: 139-144.

Gale J L, DiGiacomo R F, Kiviat M D, Wang S-P, Bowie W R 1977 Experimental nonhuman primate urethral infection with Chlamydia trachomatis and Ureaplasma ( $\mathrm{T}$ mycoplasma). In : Hobson D, Holmes K K (eds) Nongonococcal urethritis and related infections. American Society for Microbiology, Washington DC, pp 205-213.
Johnson A P, Clark J B, Osborn M F, Taylor-Robinson D 1980 A comparison of the association of Neisseria gonorrhoeae with human and guinea-pig genital mucosa maintained in organ culture. British Journal of Experimental Pathology 61 : 521-527.

Johnson A P, Taylor-Robinson D, McGee Z A $1977 a$ Species specificity of attachment and damage to oviduct mucosa by Neisseria gonorrhoeae. Infection and Immunity 18: 833-839.

Johnson A P, Taylor-Robinson D, Slavin G $1977 b$ Pneumonia in mice produced by Neisseria gonorrhoeae. British Journal of Venereal Diseases 53 : 26-30.

Kellogg D S, Peacock W L, Deacon W E, Brown L, Pirkle C I 1963 Neisseria gonorrhoeae. I. Virulence genetically linked to clonal variation. Journal of Bacteriology 85: 1274-1279.

Kita E, Matsuura H, Kashiba S 1981 A mouse model for the study of gonococcal genital infection. Journal of Infectious Diseases 143: 67-70.

Sowter C, McGee Z A 1976 Evaluation of a new technique for the demonstration of gonococci and other micro-organisms in host cells. Journal of Clinical Pathology 29: 433-437.

Taylor-Robinson D, Johnson A P, McGee Z A 1975 Use of organ cultures and small laboratory animals for the study of gonococcal infections. In: Danielsson D et al. (eds) Genital infections and their complications. Almqvist and Wiksell, Stockholm, pp 243-252.

Taylor-Robinson D, Whytock S, Green C J, Carney F E 1974 Effect of Neisseria gonorrhoeae on human and rabbit oviducts. British Journal of Venereal Diseases 50: 279-288.

Tebbutt G M, Veale D R, Penn C W, Smith H 1977 The behaviour of Neisseria gonorrhoeae on guinea-pig mucosae in vitro and in vivo. FEMS Microbiology Letters 2: 39-41.

Tuffrey M, Taylor-Robinson D 1981 Progesterone as a key factor in the development of a mouse model for genital-tract infection with Chlamydia trachomatis. FEMS Microbiology Letters 12: 111-115. 